DIVISION OF THE HUMANITIES AND SOCIAL SCIENCES

CALIFORNIA INSTITUTE OF TECHNOLOGY

PASADENA, CALIFORNIA 91125

Rules, Discretion, and Accountability in Macroeconomic Policymaking

William R. Keech

The University of North Carolina at Chapel Hill

California Institute of Technology

To be published in Governance 5:3, July 1992

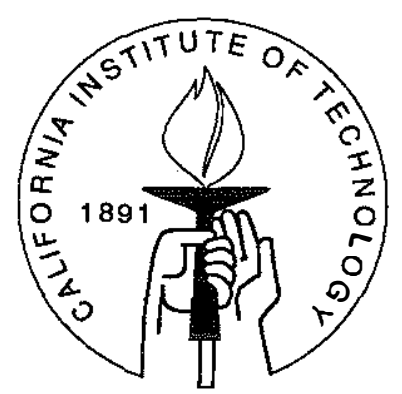

SOCIAL SCIENCE WORKING PAPER 789

March 1992 
Rules, Discretion, and Accountability

in Macroeconomic Policymaking

William R. Keech

March, 1992

\begin{abstract}
Arguments for rules rather than discretion in macroeconomic policymaking facilitate the understanding of some fundamental issues of democratic theory. This article reviews four such arguments, and relates them to issues of delegation and accountability in representative government.
\end{abstract}




\section{RULES, DISCRETION, AND ACCOUNTABILITY IN MACROECONOMIC POLICYMAKING}

Since at least the 1930s, some economists have argued that public officials should follow rules that tell them what to do, rather than use their discretion in making macroeconomic policy. This argument is receiving renewed attention, and being supported by new arguments. In all of its forms, it raises important questions for theory about democratic government. This essay reviews and evaluates the controversy in the context of more traditional political science issues of delegation and accountability. These issues are in turn illuminated by confronting the points raised in the rules versus discretion controversy. Macroeconomic policy is the focus because that is the setting for which the arguments have most of ten been developed.

I. Delegation and Accountability in Democratic Government.

In democratic governments, public policy is made by elected officials who are accountable to the electorate, or by unelected of ficials who are accountable to elected officials and to the public. Implicitly, the issue of accountability involves delegation of decision-making authority from a principal to an agent. In democratic government, it involves the delegation of authority from the public, the ultimate principal, to elected officials as agents, and from elected officials as principals to appointed of ficials as agents.

In economics and game theory the principal usually has clearly defined goals. The principal enters a contract with an agent who then pursues his or her own goals as constrained by the contract. But the agent typically has more information than the principal, which may give him or her an advantage. This information asymmetry yields problems of control which are understood as adverse selection, hidden information and hidden action. ${ }^{1}$

In democratic government, the structure is of ten much less well defined. The principal may not act first, and may not have clear goals. This is true of Congress as principal delegating powers to the bureaucracy, and even moreso of the public delegating authority to the Congress. As Kiewiet and McCubbins put it, the principal need not

be able to commit to a schedule of rewards or punishments in advance. The agent may take action in anticipation of reward from the principal. Or the principal may hire the agent "to do good things," leaving for later the specification of what constitutes good things as well as the nature of the reward for doing them (1991, p. 240).

In general, the delegation of authority may sometimes be to implement clear goals in situations in which the principal knows exactly what he or she would do, but is not in a position to do it. Alternatively, the delegation may be to make decisions that involve contingencies the principal cannot anticipate. In such cases the agent is expected to make decisions that the principal 
"would have made" in the same circumstances. Sometimes the agent helps figure out what the principal wants when the principal does not know.

Accountability is a word that is widely used as if it needed no definition or clarification, but it is used in different ways. The meanings are usually clear in context, but the concept is so widely used that it deserves more careful analysis than I have found. ${ }^{2}$ Elections are only one of the ways that contemporary institutions are designed to assure the accountability of public officials. The term accountability has at least two relevant meanings. One is to be subject to the need to give account, i.e., to explain, report, or justify. The other is to be subject to sanction for inadequate performance, as in removal from office.

The need to explain, report, or justify is thoroughly incorporated into American political institutions. The Constitution provides that the President "shall from time to time give to the Congress Information of the State of the Union". Members of Congress report by mail and in person to their constituents on their activities and accomplishments. Court decisions are handed down in documents that explain and justify their content in terms of precedent and legal reasoning. The President and the Council of Economic Advisors issue annual reports describing the recent performance and future prospects of the economy, and explaining or defending the part their policies played therein.

All of these examples of accountability by giving account reflect the presumption that there should be good reasons for public decisions, regardless of whether the goals or standards are specified in advance. The examples vary in the degree to which the possible courses of action are expected to be constrained. In court decisions, statutes and precedents restrict and perhaps even define the nature of the decisions that can be made, limiting the discretion available to judges. In contrast, elected officials are of ten expected to be identifying new problems and taking new initiatives in ways that are not so constrained. Their reports are likely to be one-sided if not selfserving. Only the naive expect pure "objectivity" in these statements. They are designed to justify, to persuade, and to generate support. The standards to which they appeal may be narrowly defined, as in the case of courts or administrative agencies. Or they may be broad and subject to redefinition by the report itself, as in the case of legislators and elected executives.

The other kind of accountability is to be subject to sanction, such as removal for inadequate performance. All public institutions in American government provide that officials are subject to removal in one way or another. ${ }^{3}$ The possibilities range from federal judges to members of the House of Representatives. Judges "shall hold their Offices during good Behavior", subject only to impeachment for serious misconduct. Members of the House, however must face an election every second year. 
These different institutional arrangements carry different presumptions about the burden of justifying continuation in office. In the case of judges appointed for life, there is a very heavy burden of argument on anyone who would remove one of them from office. Removal by impeachment implies extraordinary cause, and as a result of a trial-like proceeding. In the absence of such cause, continuation in office is simply the default. No positive action is necessary. Effectively this leaves enormous discretion in the hands of judges.

In contrast, the legislator does not continue unless actively..chosen every second year. The burden is normally on him or her to make a case for re-election relative to a concrete and viable alternative. No rationale for removal is needed beyond the ability of some alternative candidate to demonstrate that he or she is more preferred than the incumbent as measured by counting votes. This is what Hanna Pitkin calls accountability as a formalistic view of representation $(1967,55-$ 59).

Yet while periodic elections are the central institution by which some public officials are held accountable to the electorate, even the simplest elections have a complicated task. Even an election with only two candidates for a single of fice is simultaneously an institution of accountability for past performance and an institution of choice over future alternatives. The study of the politics of macroeconomic policymaking has produced analyses that emphasize each of these features. For example, the study of policymaking behavior that involves cycles on electoral periods highlights retrospective issues of accountability, whereas the study of policymaking behavior that involves differences between partisan alternatives emphasizes forward looking issues of choice. The standard of accountability for past performance is likely to be influenced by the attractiveness of the alternative and the clarity of the official's responsibility for performance.

But how can such accountability be defined? Performance can be assessed according to whether it measures up to standards regarding outcomes and results, i.e. outcome standards. Or performance can be deemed accountable according to whether it conforms to procedural standards. These might involve the process by which a decision is made, such as following a public hearing, or following a prescribed voting procedure. Or they might involve a process such as an election, in which the agent in the position of delegated authority might be removed. Political science of ten focuses on procedural institutions and procedural standards, like those in elections and courts. Economics is much more oriented to evaluating outcomes, such as interest rates, money growth, budget balance, output, inflation, and unemployment in relation to externally defined standards. In political analysis, outcomes are of ten considered to be validated by the procedures that produced them. Economic analysis offers external standards for outcomes that may provide a benchmark against which procedures can be evaluated. 
If we use procedural standards to achieve accountability, the problem reduces to deciding what institutions or procedures are appropriate. For example, if the only standard for accountability is the capacity of an incumbent to secure a majority in a two candidate race, accountability may be achieved by definition. Incumbent victory or loss defines whether performance is deemed adequate or inadequate. However, such procedural standards for accountability are not always seen as adequate, as is indicated by the movement to limit the number of terms elected officials can serve. The case for rules rather than discretion in macroeconomic policymaking is a proposal to use outcome standards instead. ${ }^{4}$ Of ten the case grows out of a presumption that democratic institutions produce policy outcomes that are inferior to alternative possibilities, usually excessive public deficits or inflation.

\section{Rules and Discretion.}

How much discretion and latitude should public officials have in making decisions? Under the Constitution of the United States, the range of decisions by public officials on both the federal and state levels is not unlimited, but except for applications of the Bill of Rights, the scope of these limitations has become very narrow as a practical matter. Outside of constitutional law, there are other sources of the claim that rules should restrict the discretion of economic policymakers. The idea goes back at least to economist Henry Simons, who argued that "a stable framework of definite rules" should be designed to assure "a minimum of uncertainty for enterprisers and investors" (1936, 29). Milton Friedman has been a persistent advocate of similar ideas since the 1940s, and the case for rules is enjoying a resurgence in contemporary economics, based on the ideas of rational expectations and game theory.

This paper is meant to bring some of the arguments to the attention of the political science community. ${ }^{5}$ Because of recent experience, they should not be totally unfamiliar. The GrammRudman-Hollings law, which defined a mandatory schedule for reductions in the federal budget deficit, showed that there has been Congressional support for rules that would restrict the results of majority rule legislative policymaking. And the proposal that a balanced budget rule be placed in the Constitution has consistently received very extensive public support for several years. However, the energy behind most of the interest that contemporary economists have in rules derives less from dissatisfaction with policy outcomes, than from theory, specifically rational expectations and game theory.

There are four main sources of the case for rules that would restrict the discretion of public officials in macroeconomic policymaking. One hinges on the limitations of human intellectual capacities or the availability of relevant information. The second regards the goals of public officials and their vulnerability to inappropriate political incentives. The third depends on the possibility that even the most rational, informed, and public spirited of ficials will do things 
that would be better constrained by rules. The fourth involves the implications of information asymmetries between policymakers and the public.

1. Limitations of knowledge and information. Milton Friedman has for decades been a critic of discretionary monetary policy, and an advocate of automatic policy. He is most closely identified with the proposal for a rule-based policy of a fixed rate of money growth, but his original proposal was different, and somewhat more complicated. In "A Monetary and Fiscal Framework for Economic Stability" (1948, 1953), Friedman proposed a four point plan integrating the two kinds of policy. He then advocated a $100 \%$ reserve banking system, and the elimination of discretionary monetary stabilization authority through all three major instruments: open market operations, rediscounting, and the setting of reserve requirements. His fiscal proposals were for a system of automatic stabilizers. These would involve some value judgments for public policymakers: to determine the levels of government expenditures on goods and services, and on transfer payments, and to determine the rates in a progressive income tax. The automatic stabilizers were to operate entirely through transfer payments and the income tax, which would fluctuate countercyclically with business cycles, while other public expenditures would be set in terms of long term values: "the community's desire, need and willingness to pay for public services" (1953, 136).

In this proposal, Friedman suggested a rule-based monetary policy that is quite different from the constant money growth with which he has become identified. In 1948 he proposed that the monetary authority would create or retire money automatically on a dollar for dollar basis to deal with a business cycle-induced deficit or surplus. Although this initial proposal would yield to a simpler proposal to be discussed below, both share his consistent rationale that there are serious limitations of our knowledge, indeed "ignorance about lags and about the fundamental causes of business fluctuations" $(1953,144)$, and that there are "long and variable" lags between policy action and economic response. In such a world, discretionary government action to deal with the business cycle is more likely to destabilize than stabilize. While Friedman acknowledged that even automatic stabilization might actually destabilize, he argued that it was less likely to do so than discretionary policy, because of the lag between "the need for action and the recognition of that need" $(1953,145)$. This early article did anticipate later observations by recognizing risks of "irresponsible government action and ... inflation" through explicit control of the quantity of money, and that the "principle of a balanced stable budget" might not be able to command effective consent $(1953,156)$.

In A Program for Monetary Stability, (1960) Friedman uses the same rationales of limited knowledge, and of long and variable lags between monetary policy actions and their consequences to argue in favor of a simple rule to guide monetary policy. Such a rule should offer a clear 
criterion for measurement of performance," so that there should be no doubt about success or failure. Also, the performance indicator should be directly linked to the instruments that a policymaking body controls, so that responsibility for success or failure is unambiguous and cannot be shifted.

He rejects the price level as the appropriate criterion for performance, because "the link between price changes and monetary changes over short periods is too loose and too imperfectly -known to_make price level stability an objective and reasanably unambiguous guide to policy" $(1960,87)$. Instead of the price level, Friedman proposes the money supply as the criterion for a rule. The money supply is much more directly under the control of the Federal Reserve, and they can much more reasonably be held responsible for its behavior. As he puts it, the Fed controls its own earning assets, which affect the money supply within limitations introduced by the behavior of other governments, the Treasury, banks, and the public. He proposes reforms that would eliminate those limitations (1960, 88-89).

By virtue of being simpler, and dealing only with the money supply, this rule would be more easily understood by the public, and less vulnerable to opportunistic tinkering than his previous proposal outlined above. Friedman argued that the simple rule of a steady four percent rate of increase in the stock of money would have avoided a series of mistakes made by discretionary monetary policy since the 1920 s, and would have made for much better economic performance. The main alternative to the proposed fixed rate of money growth is "let the Federal Reserve System do it", which provides no well defined criterion for judging whether they have done well or badly (1960, pp. 93-98).

Friedman's argument depends heavily on identifying criteria for evaluating performance, and offers little for assuring enforcement. He does not say what would be done if the Fed failed to meet its targets, and he seems to expect that a clear rule would be substantially self-enforcing. In choosing between between something more important as a final goal and less controllable (like the price level), relative to something less important but more controllable (like the money supply), Friedman does not hesitate to choose the latter. However, even though this seems like looking for lost keys under the streetlight, the argument is more subtle. Given our lack of knowledge, and given a record in which discretionary policy is presented as destabilizing, following this rule for an intermediate target is presented as a better way to achieve feasible values of final goals than any known alternative.

In Capitalism and Freedom, Friedman adds a feature to his argument by making an analogy with the First Amendment to the U.S. Constitution. Treating each case on the merits is less likely to provide effective and meaningful freedom of speech because of the nature of the shifting majorities of the moment. Even if it did, he contends 
that a general rule is preferable to doing what seems right in every specific instance on a case by case basis. A general rule "has favorable effects on people's attitudes and beliefs and expectations that would not follow even from the discretionary adoption of precisely the same policy on a series of separate occasions" $(1962,53)$.

In "The Role of Monetary Policy" (1968) Friedman explains why monetary policy cannot persistently control unemployment rates, and reiterated his arguments for a steady money growth rule, emphasizing again the importance of lack of knowledge and the importance of having the monetary authority guide itself by magnitudes it can control, like the money supply, rather than those it cannot, like interest rates, prices, and unemployment.

The passage by Congress of Concurrent Resolution 133 in 1975 seemed to Friedman at the time as "perhaps the most important change (in the structure of monetary policy) since the banking acts of the mid-1930s" because it specified monetary aggregates as the Fed's immediate target, instructed the Fed to produce steady money growth in line with output growth, required the Fed to state its objectives in advance, and required that the Fed justify publicly any deviations from them $(1982,107-108)$.

Unfortunately, this acceptance of monetarist principles did not, according to Friedman, change behavior. Fed reports to Congress have, he says, a "common script". When things go well, the Fed takes full credit. When things go badly, limited powers and unpredictable external events are blamed. "The statements of general principles and desirable policies are always excellent ... The explanation of defects in past performance is always ad hoc and exculpates the Fed" (1982, 115-116). In effect, Friedman is saying that accountability by "giving account" is unsatisfactory and inadequate. Implicitly he is suggesting that self-imposed rules may not be self-enforcing.

Friedman's recent observations have moved in the direction of strengthening incentives and enforcement mechanisms, and in the direction of accountability by being removable for poor performance. In Free to Choose, he uses the analogy of alcoholism to explain why money growth continues to be too fast, and he proposes a constitutional amendment to add stature to the proposal of a fixed rate of monetary expansion (1980, 270, 307-8). In his 1981 Money, Credit, and Banking Lecture, he raises and dismisses as unfeasible the possibility of requiring Fed Governors to submit resignations in years in which money growth exceeded targets, and suggests ending Fed independence by putting it in the Treasury or under direct Congressional control (1982, 117-118). (In my terms, this would be a move in the direction of increasing accountability.) In Tyranny of the Status Quo, he presents the constitutional amendment and the proposal to put the Fed under the Treasury as alternatives that are each preferable to things as they are (1984, 100-101).

In general, Friedman's arguments do not depend on perverse motivations or lack of rationality of public officials. They hinge on limitations in the capacities of eveñ the môst fülìy 
informed and public spirited agents to foresee and control. ${ }^{6}$ In such a world this argument for rules seems to be designed to convince public-spirited policymakers that they would be better off in their own terms if they would follow rules. Friedman seems to have expected that this point, once accepted, could be self-enforcing.

Even though Friedman's case for rules does not hinge on an explicit theory of perverse discretionary political behavior, his supporting arguments include a litany of cases in which discretionary mistakes could have been avoided by a rule. Coincidentally, while Friedman is not personally associated with theory or research on electoral cycles in economic policy, his presidential address to the American Economic Association (1968) was an early articulation of a theory of economic behavior that became the basis for the seminal modern article on "the political business cycle" (Nordhaus, 1975).

2. The goals of public officials and the limitations of the political process. Traditionally, the analysis of macroeconomic policymaking has assumed, as Friedman implicitly does, that public officials were public spirited rather than selfish, and that the political process was an adequate means of providing accountability, or at least not a source of perverse incentives. Economics has of ten treated the generic policymaker as a "benevolent dictator", maximizing some conception of public welfare. The political process has of ten been treated as exogenous, and not modelled or subjected to economic analysis.

This view is at odds with another characteristic of economics: the assumptions that individuals are rational, and that rational individuals are selfish utility maximizers. The subdiscipline of public choice has applied this presumption to policymakers as well as to economic agents. No-one is more closely identified with this view than James Buchanan, who, with his colleagues, develops it into an argument for constitutional rules in general, and for rules rather than discretion regarding macroeconomic policy in specific.

Buchanan's arguments are based on two components: a modern view of government as Leviathan, and a view of the limitations of the political process. The term Leviathan of course evokes Hobbesian images of authoritarian and unaccountable government, but Buchanan is explicit in arguing that "Democracy may become its own Leviathan unless constitutional rules are imposed and enforced" $(1975,161)$.

In The Power to Tax, he and Geoffrey Brennan explicitly reject models of government as benevolent despotism and as constrained by median voter preferences. Even democratic government is seen as monolithic and malevolent or indifferent, rather than benevolent. These presumptions are defended less as a description of reality than as a way of anticipating what might occur, and as a way of recognizing "inherent tendencies" (1980, ch. 2). 
Just as government is not inherently benevolent,- the political process is not an effective instrument of accountability.

Specifically, we assume that the political process ... is not effectively constrained by electoral competition as such, and that the electoral process can appropriately constrain the natural proclivities of government only when it is accompanied by additional constraints and rules imposed at the constitutional level (Brennan and Buchanan, 1980, 15).

... This is because some principles, like property rights, are too important to be subject to majority rule, because of well known arbitrary features of majority rule, and because "the broad brush of history" regarding growth of government suggests that the normal electoral process has not kept government power "within acceptable bounds" (ibid., 17-26).

Buchanan's most explicit arguments about the limitations of the political process in a macroeconomic context are in Democracy in Deficit (1977), with Richard Wagner, a critique of Keynesian economics as implemented in a democratic political system. Before Keynesian economics became politically acceptable, norms of budget balance assured that increases in public expenditure would be covered by increases in taxes. Such a connection helped assure that the demand for public expenditures would be constrained by an accurate assessment of their price, and a public budget could be seen as a fair reflection of what a majority preferred to the private goods sacrificed through taxation.

However, Keynesian rationales for deficit spending to stimulate the economy out of a recession undermined these norms, and made unbalanced budgets politically acceptable. The consequence was a fundamental asymmetry in political incentives. In electoral politics, a surplus and a deficit are fundamentally different. The immediate impact of a deficit is to permit a given level of public expenditure without covering its cost in taxation. This creates immediate benefits of lower perceived prices for publicly provided goods, and no immediate adverse consequences. Conversely, a surplus means higher perceived prices for publicly provided goods and services, and foregone private consumption that implies adverse results without immediate benefits. Buchanan and Wagner find that these powerful incentives make it almost inevitable that stabilization policy will be applied asymmetrically by being biased away from budget surpluses, and towards deficits.

A Keynesian fiscal remedy for a recession is to increase public expenditures or to cut taxes. Either choice is politically attractive in its own right. However, when there is no such stabilization rationale for a deficit, the political incentives for lower taxes or higher expenditures remain, without being constrained by the balanced budget norm. If there is a stabilization rationale for increasing taxes or cutting expenditures, it is likely to be resisted by the same forces that supported the opposite course of action. 
Monetary authorities may also be involved. A politically insulated monetary authority could decline to accommodate government deficits with growth in the money supply. Such a stance would leave the long term consequences of the asymmetry as merely "a regime of budget deficits, a biased increase in the rate of growth of the public sector, a regime of unduly high interest rates, and a slowdown in the rate of private capital formation (Buchanan and Wagner $1977,113)$. However, if the monetary authority responded to political pressures with increases in money growth in order to accommodate the deficits, inflation will be an added consequence of the Keynesian policy regime. ${ }^{7}$

To deal with the asymmetry in the incentives of fiscal policy, Buchanan and Wagner have proposed a rule in the form of a constitutional amendment that would limit the discretion of public officials to create federal budget deficits under most circumstances (1977, ch. 12). Elsewhere, Brennan and Buchanan advocate a "monetary constitution" as well. They are less concerned with the specific form of monetary rules than with establishing the principle that some form of rules is superior to existing discretion in monetary policy $(1982,58-65)$.

Buchanan and his colleagues write on a broad philosophical level and concentrate on establishing the principle that rules should guide policy. Much of the inspiration for the theory seems to come from the central idea of applying economic principles to the understanding of political behavior, but the arguments are complemented by reference to undesirable policy patterns that are explained by analysis of political motivations in an environment that is not constrained and structured by rules. They do not emphasize, as Friedman does, limitations in our understanding of the economy or its unpredictable nature. Ironically, in spite of their expectation that public officials will follow selfish incentives rather than publicly oriented goals, they pay little attention to issues of enforcing the rules they suggest.

3. The time consistency problem. Perhaps the most prominent basis in contemporary economics for an argument for rules and against discretion is called the time consistency problem. The general point is that a policy that may be the best thing to do in general may not be the best thing to do at a particular time. Two intuitive examples have to do with policy towards terrorism and patent policy. A good general rule is not to negotiate for return of hostages, because to do so adds to the incentives for terrorists to take hostages. However, once they are taken, there are powerful incentives to negotiate for their release. Similarly a policy that allows inventors to secure monopoly profits for some time is desirable as a way to encourage innovation. However, once a product, such as a drug to treat AIDS, is invented, there are incentives for policymakers to allow competition, in order to bring the price down. The time consistency problem is modelled as a repeated game. 
Barro and Gordon (1983) developed the argument, introduced by Kydland and Prescott (1977), that this idea might be relevant to macroeconomic policy. The argument does not depend on either the lack of knowledge highlighted by Friedman, or on the conflict of interest between government and the public highlighted by Buchanan. Indeed, it assumes a high degree of knowledge and rationality for both policymakers and publics, and a basic congruence of interests between them. The basis for the macroeconomic application is a mixed motive, prisoners' dilemma type.interaction between the public and the government.

A central feature of the extensive literature building on this problem is the assumption that the government, i.e. the monetary authority, wants to stimulate output beyond its equilibrium growth rate. This rate, which corresponds to the "natural" rate of unemployment, is that which exists when inflation is equivalent to expected inflation. Without this goal, which is not necessarily at odds with the public, this particular version of the argument for rules collapses.

Why would the government want to stimulate the economy beyond the rate that can be sustained without inflationary surprises? The stated rationale is that the equilibrium output is too low from the point of view of general social welfare. The reason is usually either labor market distortions, such as unions or minimum wage laws, or a tax system that creates other distortions that have a similar effect. As Canzoneri $(1985,1058)$ points out, a first best solution to these problems would be labor legislation or fiscal policy reform. This literature does not document the assertion that governments try to stimulate output in this way, or for this reason. ${ }^{8}$

Still, once the assumption is made, interesting theoretical results emerge in a world characterized by rational expectations and an expectational Phillips curve. The public determines wages on the basis of expected inflation, knowing that the government wishes to expand output with an inflationary surprise. But if the public expects the inflation producing spurt in money growth, both the public and the government lose. Neither side wants the inflation that results, and, since the inflation is expected, it does not generate the increase in output that the government desires. The time consistency problem emerges because the government wants the public to think that it will not inflate. But if it were to succeed in creating that expectation, it would create an inflationary surprise in order to produce a desired increase in output. As several of the contributors to this literature have pointed out, a solution to this problem is a rule, such as a committment to a constant money growth as an alternative to discretion.

The basis for this argument for rules is much less intuitive than those of Friedman and Buchanan. Indeed, it might be characterized as artificial and contrived, especially to those not familiar with contemporary macroeconomics. However, the time consistency literature has important strengths not present in the previous two arguments: it includes explicit state of the art models of the macroeconomy, and it does not assume that the establishment of a rule will be self- 
enforcing. Rather it considers at length the structure of incentives for public officials to follow or deviate from a rule. It introduces the concept of reputation as a possible incentive to follow rules.

Even though policy under a rule is better than policy under discretion, the policymaker has an incentive to cheat given the expectation that he or she will follow the rule. However, cheating undermines the credibility of the reputation for following a rule. Barro and Gordon (1983) show that for the ideal rule with an inflation target of zero, the value of the temptation to cheat will exceed the enforcement value of lost reputation given a positive discount rate. However, they show that reputational forces may be sufficient to support self-enforcing rules for positive rates of inflation that are lower (better) than the discretionary equilibrium.

Ironically, the possibility of maintaining such desirable reputational equilibria may be hindered, rather than helped, by periodic elections, the main institutional basis for assuring accountability of public officials in a democracy. The reason is that elections eliminate the unlimited time horizon on which the reputational equilibria depend (Barro 1990, 15-16). The possibilities of repeated election, and of parties rather than individuals developing reputations, however, might lengthen the time horizon.

Scholars have investigated the behavior of models in which the public officials are of different types. Backus and Driffil (1985) analyze the behavior of policy when the public does not know at first whether a government is hard nosed or "wet", and must learn by observing its behavior. Alesina (1987) analyzes policymaking under rules and discretion when there are two parties with differing clienteles and objectives, and characterizes reputational equilibria for each party.

While this literature contrasts pure discretion, reputational equilibria, and binding commitments to an optimal rule, it says rather little about how binding commitments might be enforced. Furthermore, as it recognizes that the world of stabilization policy is stochastic rather than deterministic, it raises some questions that undermine the case for simple rules and move arguments in the direction of discretion. For example, Canzoneri (1985) has addressed the possibility that, although noncontingent rules may effectively deal with the time consistency problem, they may deny the policymaker the capacity to deal with disturbances such as supply shocks, and to stabilize output. He identified a tradeoff between the discretion needed for effective stabilization policy, and the rules needed to deal with the time consistency problem. Alesina (1987) extends this issue into a world in which parties have different objectives.

In a world of stochastic shocks to the macroeconomy, the desirability of simple, noncontingent rules might give way to more complicated rules in which given actions are contingent on the state of the world that is observed. Given all of the contingencies, such rules might become very complex..$^{9}$ Alesina shows that the preferability of a contingent rule to a 
simple rule depends on the size of the shocks to the economy, and on the relative concern with price versus output stabilization:

This argument may rationalize why economists have disagreed about the relative merits of rules versus discretion: even if economists and policymakers agreed on the description of the economy (and they probably do not!) they still disagree on the issue of the superiority of "simple rules", because the relative weights in their objective functions may be different $(1987,20)$.

This suggests that the choice of rules is a matter of political values and preferences as well as objective analysis.

The time consistency literature largely sidesteps the possibility of a conflict of interest between policymakers and public. ${ }^{10}$ While it readily incorporates a view of the economy as stochastic, for it, the stochastic nature of the economy undermines the case for rules, rather than being the basis for it, as it is with Friedman. Of the three cases for rules we have seen so far, it is the one that is most sensitive to the question of whether or not rules will be obeyed.

4. Asymmetric information. Cukierman and Meltzer (1986) place the issue of rules and discretion in a broader context of information asymmetry between policymakers and the public in a stochastic world that does not depend on the time consistency problem. They identify conditions under which rules may be superior to discretion, but suggest that enforcement problems may not be solvable.

Cukierman and Meltzer contrast government as benevolent planner with government motivated by the desire for re-election. The task of the government is to maximize welfare by setting policy instruments in a way that corresponds to stochastic disturbances, for which it has superior information. In this world, flexibility is important, so that decisions can be made with maximum information. Since the best decisions are contingent on the nature of the shocks observed, any policy rule must be contingent, unlike most of those suggested in the previous sections. The optimal rule is a contingent one that simply describes what the benevolent planner would do under discretion.

If government officials were benevolent planners (as economists used to assume), such rules would be redundant. Ironically, however, periodic elections, a central institution of government accountability, may themselves provide incentives to deviate from optimal policy. The reason is that the best policy is defined in terms of appropriate settings of policy instruments, given information about shocks. But for the final period the public only observes performance, rather than the shock and the government response. The government maximizes its prospects of re-election by optimizing performance just before the election, even at the risk of sacrificing post-election welfare for pre-election welfare (Cukierman and Meltzer, 1987, 373-377). 
When the public uses realized welfare during incumbency as the criterion for the evaluation of future performance of the government, maximization of the likelihood of being elected is incompatible with the maximization of social welfare. The loss of social welfare is directly traceable to the existence of periodic democratic elections, so we have called it "the cost of democracy" $(1986,377)$.

Even though a contingent rule that duplicates the discretionary actions of the benevolent planner could improve policy, it cannot be enforced in the warld described, because only the government has the information in time to see that it is followed. In order to enforce the rule, the enforcement authority must have the same information as the government. If the public has the same information as the government, the problem does not arise. If the public does not, we seem to have returned to Plato's problem of "who will guard the guardians?" Cukierman and Meltzer have identified a paradox of democratic government. In a simplified world involving stochastic shocks demanding government response and information asymmetries between public and government, elections themselves have a welfare cost relative to the best possible decisions. Furthermore, rules to require such decisions are unenforceable.

With Cukierman and Meltzer, the case for rules seems to unravel. For them, the divergence of motives between public officials and the public is (ironically) introduced by the existence of periodic elections. For them, the stochastic nature of the economy does not so much either make or undermine the case for rules as it does in the other arguments. In their analysis the existence of shocks is the main basis for an information asymmmetry between public of ficials and the public, and this asymmetry is the reason rules cannot be enforced.

III. Rules, Discretion, and Accountability.

The first two rationales for rules (those associated with Friedman and with Buchanan) were guided by a mixture of theoretical premises and of dissatisfaction with patterns of outcomes. Some of the contemporary efforts to impose policy rules reflect an attempt to deal with dissatisfaction with public policymaking that is congruent with these rationales. These efforts attack problems of the accountability of public officials by specifying in advance what the officials should do. Concurrent Resolution 133 of 1975 allowed the Fed to define its goals in terms of rates of money growth chosen in advance. The Humphrey-Hawkins Act of 1978 defined the goals in terms of inflation and unemployment. The Gramm-Rudman-Hollings Acts of 1985 and 1987 defined them in terms of budget deficit targets.

Only Gramm-Rudman-Hollings involved enforcement mechanisms (the sequester), and the targets defined in all of these "rules" have been regularly and widely missed, in spite of the fact that the officials who were responsible have been accountable in both of the ways identified above. (The Economic Report of the President and the reports and testimony of the Federal 
Reserve chairman reflect accountability in the sense of explaining, reporting, and justifying. The President and members of Congress are subject to removal in periodic elections.) The movement to limit Congressional terms reflects dissatisfaction and frustration with both forms of accountability, such that officials would have to leave office at a certain point, regardless of their performance.

The last two rationales for rules were driven by theoretical concerns that are prominent in contemporary macroeconomic analysis more than by a reaction to dissatisfaction with public policy. Although these rationales respond less to specific public problems, they are very instructive in identifying the difficulties of choosing and enforcing rules. This contemporary theory offers great potential for further understanding of these issues. In general, macroeconomic theory is a revealing area in which to study issues of discretion and accountability because it is rich in theories about how the world works, and how political choices can affect outcomes.

Yet the economic analysis brings us back to concerns that are even broader than economic theory. Philippe Nonet (1980) identifies accountability and responsiveness as two conflicting demands of purposive action. When we empower officials to reason from purpose (as we typically do with elected officials and independent central bankers), "we deliberately permit decisions that elude criticism and justification and thus allow a large measure of unaccountable or discretionary authority" (273). Borrowing the language of statistics, Nonet identifies Type I error as inappropriately departing from authoritative policy, or opportunism. This is the problem that the rules we have been discussing is designed to solve. However, efforts to avoid Type I error run the risk of Type II error, which involves uncritically and inappropriately adhering to authoritative policy, or formalism (277-278). This is the risk that following the rules will be at the expense of the achievement of broader purposes when that risk is not anticipated in the formulation of the rule. Of course, rules that incorporate contingencies are designed to anticipate Type II problems. But contingent rules are most subject to the asymmetric information kinds of enforcement problems identified by Cukierman and Meltzer.

Rules for macroeconomic policymaking are based on theory about how the world works. But in its present state, macroeconomic theory does not yield an understanding of the way the world works that is sufficiently clear and authoritative to make a solid case for rules. Macroeconomics is a topic in which the outcomes of interest are only partially determined by the actions of the government. In such settings, it is difficult "to infer the appropriateness of the agent's actions even from the observed results" (Kiewiet and McCubbins, p. 26). A failure to hit a target may be legitimate or defensible because of stochastic shocks, the actions of other public and private agents, or even the effort to fulfil other public goals that are not recognized in a rule. Or 
such a failure may not be defensible, because of opportunism or incompetence on the part of the officials responsible. Rarely is it easy to tell the difference.

Neither the arguments for rules outlined in our review, nor the experience with rules just mentioned provides much encouragement for improving policy by specifying in advance what policymakers should do. Cukierman and Meltzer defined "the cost of democracy" in terms of the difference between what a benevolent planner and a vote-motivated politician would do. The literature on macroeconomic politics has made great strides in conceptualizing (if not measuring) such costs by producing models that relate political behavior under democratic institutions to policy outcomes.

But democratic institutions in the United States, for example, were developed to provide a procedural basis for accountability relative to George III, not an idealized benevolent planner. Neither modern public choice nor traditional democratic theory provide a basis for expecting that democratic institutions will ever be costless relative to the choices of such a planner, even insofar as those choices can be defined.

Democratic institutions define procedures for selecting and removing the officials who make public policy. Often they also define what public officials must or must not do. Sometimes these mandates are enforceable in courts of law. For macroeconomic policymaking and performance, it is hard to imagine rules that are legally binding in this sense. But both experience and logic suggest that limiting the discretion of policymakers by rules without enforcement mechanisms is unlikely to succeed. Perhaps suggestions that resignations be required in periods in which targets are not met should be taken more seriously. In the absence of such mechanisms, the rules are likely to become pious statements of intention. Humphrey-Hawkins and GrammRudman-Hollings iaws may be examples of "position-taking", but such piety is not harmless. Failure to fulfil the goals so defined may undermine rather than strengthen democratic institutions. 
I would like to thank Henry Chappell, Kenneth Coleman, Thomas Hammond, Roderick Kiewiet, Laura Langbein, Michael Munger, Joseph Rees, Donald Searing, and Stephen Weatherford for their comments on a previous version.

1. See Fiorina and Shepsle, 1989, for an introduction to agency theory. See also Kreps (1990), chapters 16, 17.

2. Hanna Pitkin (1967; 55-59) has the most useful discussion I have seen. She sees accountability as one of two formalistic views of representation, and as a corrective to the alternative, authorization. In this view, the formal procedure is holding to account through periodic elections. The accountability view "is not an important strand in the literature of representation; so far as I know, no writer has discussed it at length or developed it into a theoretical system, as Hobbes does with authorization" (p. 55).

3. See Fisher, 1991, chapter 3, for a discussion.

4. The term rules can be applied to procedures as well as outcomes. For example the procedures for counting votes in an electoral or legislative context are rules. In this paper, however, given its focus on the way the term is used in economic analysis, rules will be used to mean standards for outcomes.

5. For general discussions of rules and discretion by leading economists, see Blinder (1987), Bryant (1980), Fischer (1990), and McCallum (1989).

6. In a similar vein, Allan Meltzer argues that neither the Federal Reserve nor private forecasters have been "able to forecast, on average, whether the economy will be in a boom or a recession one or four quarters ahead", implying that compensatory policy actions are misguided and that rules are preferable $(1987$, p. 6$)$.

7. Brennan and Buchanan do not see these issues as implying that politicians or publics are "irrational". They see them more as self-command and time horizon problems (1985, ch. 5).

8. Cukierman (forthcoming) develops much more elaborate arguments for this core assumption, based in theories about labor markets, government revenue motives, etc..

9. Lohmann (1992) proposes a solution to this problem: a conservative central banker, who generates a low time-consistent rate of inflation at the expense of a distorted response to output shocks. The need to accommodate extreme shocks is met by a capacity to dismiss the banker, but the temptation to dismiss is reduced by an institutionalized cost to the policymaker of doing so.

10. For a major exception, see Cukierman, forthcoming. 
References

Alesina, Alberto. 1987. Rules, Discretion, and Reputation in a Two Party System. I 1 Giornale degli Economisti 48:3-27.

Backus, David and John Driffil. Inflation and Reputation. American Economic Review 75:530-538.

Barro, Robert J. 1990. Macroeconomic Policy. Cambridge: Harvard University Press.

Barro, Robert J. and David B. Gordon. 1983. Rules, Discretion and Reputation in a Model of Monetary Policy. Journal of Monetary Economics 12:101-121.

Blinder, Alan S. 1987. "The Rules-versus-Discretion Debate in the Light of Recent Experience" Weltwirtschaftliches Archiv 123:399-414.

Brennan, Geoffrey and James M. Buchanan. 1980. The Power to Tax: Analytical Foundations of a Fiscal Constitution. New York: Cambridge University Press.

Brennan, Geoffrey and James M. Buchanan. 1981. Monopoly in Money and Inflation: The Case for a Constitution to Discipline Government. London: Institute of Economic Affairs.

Brennan, Geoffrey and James M. Buchanan. 1985. The Reason of Rules: Constitutional Political Economy. New York: Cambridge University Press.

Bryant, R. 1980. Money and Monetary Policy in Interdependent Nations Washington: The Brookings Institution.

Buchanan, James M. 1975. The Limits of Liberty: Between Anarchy and Leviathan. Chicago: University of Chicago Press.

Buchanan, James M. and Richard E. Wagner. 1977. Democracy in Deficit: The Political Legacy of Lord Keynes. New York: Academic Press. 
Canzoneri, Matthew B. 1985. Monetary Policy Games and the Role of Private Information. American Economic Review 75:1056-1070.

Calvert, Randall, Mathew McCubbins and Barry Weingast. 1989. A Theory of Political Control and Agency Discretion. American Journal of Political Science 33:588-611.

Cukierman, Alex. Forthcoming..Central Bank Strategy. Credibility and Independence -Theory and Evidence. Cambridge: Massachusetts Institute of Technology Press.

Cukierman, Alex and Allan H. Meltzer. 1986. A Positive Theory of Discretionary Policy, the Cost of Democratic Government and the Benefits of a Constitution. Economic Inquiry 24:367388.

Fiorina, Morris P. and Kenneth A. Shepsle. 1989. Formal Theories of Leadership: Agents, Agenda Setters, and Entrepreneurs. In Leadership and Politics, ed. Bryan D. Jones. Lawrence: University Press of Kansas.

Fischer, Stanley. 1990. Rules versus Discretion in Monetary Policy. In Handbook of Monetary Economics, eds. Benjamin M. Friedman and Frank H. Hahn. New York: North-Holland.

Fisher, Louis. 1991. Constitutional Conflict Between Congress and the President, 3rd ed. Lawrence: University Press of Kansas.

Friedman, Milton. 1948, 1953. "A Monetary and Fiscal Framework for Economic Stability" American Economic Review 38:245-264, reprinted in Friedman, Essavs in Positive Economics. Chicago: University of Chicago Press.

Friedman, Milton. 1960. A Program for Monetary Stability. New York: Fordham University Press.

Friedman, Milton. 1962. Capitalism and Freedom. Chicago: University of Chicago Press.

Friedman, Milton. 1968. The Role of Monetary Policy. American Economic Review 58:117. 
Friedman, Milton and Rose. 1980. Free to Choose. New York: Harcourt Brace Jovanovich.

Friedman, Milton. 1982. Monetary Policy: Theory and Practice. Journal of Money, Credit. and Banking 14:98-118.

Friedman, Milton and Rose. 1984. Tyrrany of the Status Quo. New York: Harcourt Brace Jovanovich.

Heiner, Ronald. 1983. The Origin of Predicable Behavior. American Economic Review 73:560-595.

Heins, A.J. 1963. Constitutional Restrictions against State Debt Madison: U W Press.

Kiewiet, D. Roderick and Mathew D. McCubbins. 1991. The Logic of Delegation. Chicago: University of Chicago Press.

Kreps, David M. 1990. A Course In Microeconomic Theory. Princeton: Princeton University Press.

Kydland, Finn W. and Edward C. Prescott. 1977. Rules Rather than Discretion: The Inconsistency of Optimal Plans. Journal of Political Economy 85:473-491.

Lohmann, Susanne. 1992. Optimal Commitment in Monetary Policy: Credibility versus Flexibility. American Economic Review 82: .

McCallum, Bennett. 1989. Monetary Economics: Theory and Policy. New York: Macmillan.

Meltzer, Allan H. 1987. Limits of Short-Run Stabilization Policy. Economic Inquiry 25:114.

Nonet, Philippe. 1980. The Legitimation of Purposive Decisions. California Law Review 68:263-300.

Nordhaus, William. 1975. The Political Business Cycle. Review of Economic Studies 42:169-190. 
Persson, Torsten and Guido Tabellini. 1990. Macroeconomic Policy: Credibility and Politics. New York: Harwood Academic Publishers.

Pitkin, Hanna. 1967. The Concept of Representation. Berkeley: University of California Press.

Simons, Henry C. 1936. Rules versus Authorities in Monetary Policy. Journal of Political Economy 44:1-30. 